\title{
The Effect of Herbal Medicine on Colon Cancer Cells in Culture ${ }^{\dagger}$
}

\author{
Pelin Toros 1,**, Büşra Şen 1, Pınar K. Sönmez 1, Mahmud Özkut 1, Şamil Öztürk 1, Fatih Çöllü 2, \\ Sevinç İnan ${ }^{3}$ and İbrahim Tuğlu ${ }^{1}$ \\ 1 Department of Histology \& Embryology, Faculty of Medicine, Manisa Celal Bayar University, \\ 45140 Manisa, Turkey \\ 2 Biology, Faculty of Science and Literature, Manisa Celal Bayar University, 45140 Manisa, Turkey \\ 3 Department of Histology \& Embryology, Faculty of Medicine, İzmir University of Economics, \\ 35330 İzmir, Turkey \\ * Correspondence: torospelin@gmail.com; Tel.: +90-0536-640-83-67 \\ + Presented at the 2nd International Conference on Natural Products for Cancer Prevention and Therapy, \\ Kayseri, Turkey, 8-11 November 2017.
}

Publish: 14 November 2017

\begin{abstract}
Medicinal herbs are being increasingly recognized as useful complementary treatments for cancer. Colon cancer is the third most common cancer in men and the second in women worldwide. Colon cancer diseases is very heterogeneous in terms of grade, genetics, ploidy, and oncogene/tumor suppress or gene expression and its biological, hormonal, and molecular characteristics are extremely complex. In this study our aim was to identify the effect of different medical plants Viscum album, Inula viscosa, Hypericum perforatum, Lysimachia nummularia, Oleocanthal, Pinus pinaster and Rubus caeisus on colon cancer cell line. Colo320 cancer cells and human adipose tissue derived mesenchymal stem cell were analysed for four medical plants in culture. Firstly, the cytotoxicity rate (IC50) determined by MTT. After that, immunocytochemical staining were done eNOS, VEGF and TUNEL method for apoptosis. The stainings were evaluated by H-score. As a result, Inula viscosa and Rubus caeisus have a higher inhibitory effect on cell proliferation and apoptosis in both cancers than the other medicinal plants. Colo320 cancer cells expressed strong eNOS by these plants and also both plants were not toxic for adipose tissue derived mesenchymal stem cells.
\end{abstract}

Keywords: Colo 320; Herbal Medicine; Tunel; Cancer Treatment

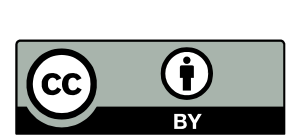

(C) 2017 by the authors. Licensee MDPI, Basel, Switzerland. This article is an open access article distributed under the terms and conditions of the Creative Commons Attribution (CC BY) license (http://creativecommons.org/licenses/by/4.0/). 